Scientific Journal Warsaw University of Life Sciences - SGGW

Problems of World Agriculture volume 17 (XXXII), number 4, 2017: 11-20

DOI: 10.22630/PRS.2017.17.4.77

\author{
Adam Andrzejuk ${ }^{1}$ \\ Warsaw University of Life Sciences - SGGW

\section{Comparison of Agriculture Biotechnology and its Spatial Diversification among Different Countries of the World}

\begin{abstract}
The importance of biotech crops have risen dramatically in the last two decades since their first commercialization. The area of those crops is increasing fast. Soybeans, maize, canola and cotton represent almost 100 percent of area cultivated with biotech crops globally. The number of countries growing biotech crops is also increasing, however currently the United States, Brazil and Argentina are responsible for the largest share of biotech crops among all countries. In 2016, those countries accounted for more than $81 \%$ of total world biotech crop area. Judging the potential to introduce new biotechnology, currently the country with the highest number of biotechnology companies is the US followed by Spain and France. In terms of spending on R\&D the US is followed by France, Switzerland and South Korea. It must be noted that the highest number of biotech companies and the highest spending is concentrated in the US. Agricultural biotechnology constitute only a small percentage of all biotechnology R\&D expenditures.
\end{abstract}

Key words: agriculture biotechnology, biotech crops, biotechnology, research and development, genetically modified crops, R\&D expenditures, countries

JEL Classification: O13, Q16

\title{
Introduction
}

In the latest report published by the United Nations - World Population Prospects 2017, the world's population is estimated to increase to 9.7 billion in 2050 (UN, 2017). The latest data from UNICEF indicates that already undernutrition contributes to nearly half of all death in children under 5 and is widespread in Asia and Africa. This translates into the unnecessary loss of about 3 million young lives a year (UNICEF, 2017). To support this level of population growth, ensure prosperity and prevent famine, more and better food will need to be produced. Some of this advancement will have to come from higher productivity through adaptation of biotechnology in agriculture. According to Food and Agriculture Organization (FAO) outlook on world agriculture: towards 2015/2030, the benefits of agricultural biotechnology arise from its potentially large contribution to productivity gains and quality improvements. Productivity gains encompass essentially all factors of agricultural production: higher returns on land and livestock, labour and capital or simply lower input requirements per unit of outputs. Biotechnology holds the promise of boosting productivity and thus raising rural incomes, in much the same way as the green revolution did in large parts of Asia during the 1960s to 1980s. It could kick-start a new virtuous cycle of productivity growth, increased output and revenues (FAO, 2003). A report by OECD

\footnotetext{
${ }^{1}$ MA, Department of Agricultural Economics and International Economic Relations, Faculty of Economic Sciences WULS - SGGW, ul. Nowoursynowska 166,02-787 Warszawa, e-mail: adam_andrzejuk@sggw.pl, https://orcid.org/0000-0002-9844-3285
} 
states that from less than $1 \%$ today, in total biotechnology could contribute up to $2.7 \%$ of the GDP in OECD countries by 2030, and considerably more in non-OECD countries. However many barriers stand in the way of the development and commercialization of biotechnologies. These include technological challenges as well as regulations, adequate investment, human resources, social acceptance, and market structures (OECD, 2009). However, it's interesting to know which countries are at the front line in developing agricultural biotechnologies. This article explores statistical data in production of biotech crops as well as distribution of biotechnology R\&D among different countries of the world. The analysis is based on data from International Service for the Acquisition of Agri-biotech Applications, FAOSTAT and OECD Health, in the time frame between 1996 and 2016. The data was developed by utilizing a comparative analysis. A deduction method was used for the assessment of events. For the purpose of this article, terms such as, biotech, GM, GE are used interchangeably.

\section{Agricultural Biotechnology}

As published in Agricultural Biotechnology Support Project (ABSP) briefs supported by USAID, agricultural biotechnology is a collection of scientific techniques used to improve plants, animals and microorganisms. Based on the understanding of DNA, scientists have developed solutions to increase agricultural productivity. Starting from the ability to identify genes that may confer advantages on certain crops, and the ability to work with such characteristics very precisely, biotechnology enhances breeders' ability to make improvements in crops and livestock. Biotechnology enables improvements that are not possible with traditional crossing of related species alone [PBS \& ABSPII, 2004]. FAO supports the argument, by stating specifically that modern biotechnology takes various forms. These include:

1. tissue culture, in which new plants are grown from individual cells or clusters of cells, often bypassing traditional cross-fertilization and seed production;

2. marker-assisted selection (MAS), in which DNA segments are used to mark the presence of useful genes, which can then be transferred to future generations through traditional breeding using the markers to follow inheritance;

3. genomics, which aims to describe and decipher the location and function of all genes of an organism;

4. genetic engineering, in which one or more genes are eliminated or transferred from one organism to another without sexual crossing. A genetically modified organism (GMO), also referred to as a living modified organism (LMO) or transgenic organism, means any living organism that possesses a novel combination of genetic material obtained through the use of modern biotechnology (FAO, 2003).

\section{Analysis}

Since the first biotech crop was commercialized in 1996, the global area of biotech crops has seen more than 100 fold increase. According to International Service for the Acquisition of Agri-biotech Applications (ISAAA), in 1996 there was 1,7 million hectares of biotech crops in the world, whereas in 2016 that area increased to 185 million hectares. 
Examining the data published by FAOSTAT, there is currently 4,9 billion hectares of agricultural area in the world in total, therefore 185 million hectares of biotech crops might not seem like much, however, according to ISAAA, biotech crops are considered as the fastest adopted crop technology in the history of modern agriculture [ISAAA, 2016]. However, it can be noticed, that in recent years the impressive growth has been leveling off, mostly due to high saturation in the production area of main crops such as Soybean and Maize in major producer countries.

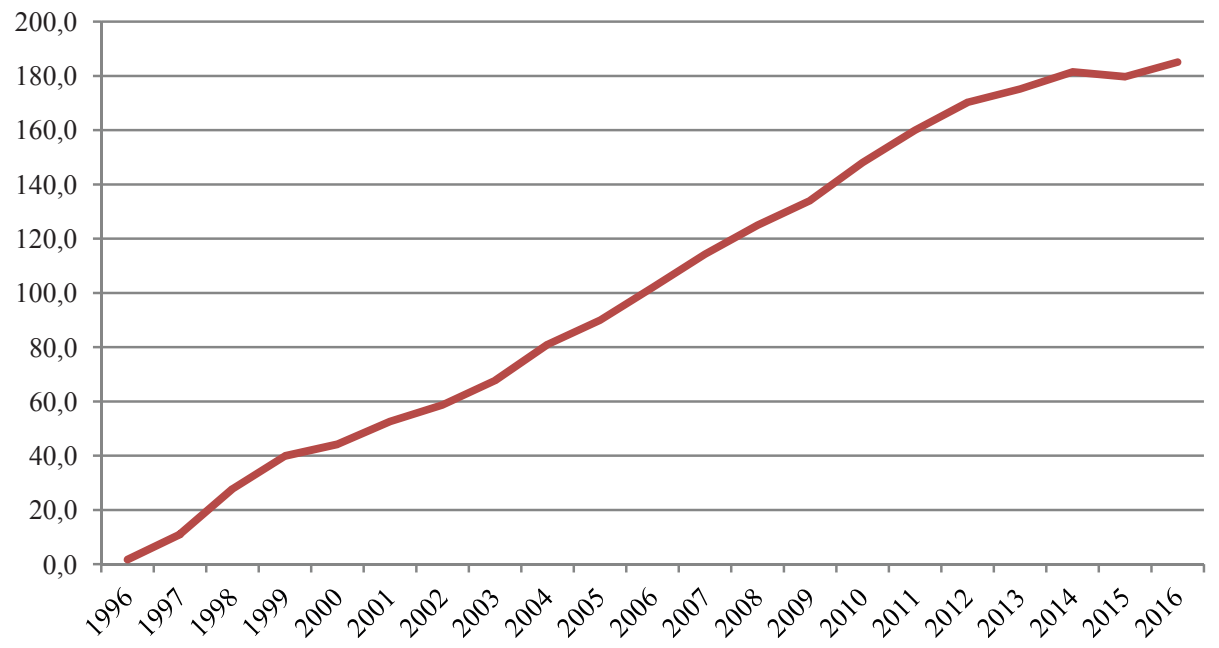

Fig. 1. Global area of biotech crops from 1996 to 2016 (millions of hectares)

Source: own study based on the data from International Service for the Acquisition of Agri-biotech Applications (ISAAA).

Looking at the distribution of biotech crops across different countries in the world it can immediately be noticed that the United States, with the area of 72,9 million hectares of crops, is responsible for the largest share of biotech crops among all countries. Brazil is the second largest biotech crop holder with 49,1 million hectares and Argentina third, with 23,8 million hectares. At the same time in 2016, the first three countries accounted for more than $81 \%$ of total world biotech crop area. Other countries, such as Canada $(11,6)$ and India $(10,8)$ are the only other holders of biotech crops with area of more than 10 million hectares. Further down the list, countries like Paraguay $(3,6)$, Pakistan $(2,9)$ or China $(2,8)$ hold much less in terms of area of biotech crops. It's worth noticing that according to ISAAA, Spain is the biggest producer of genetically modified crops in Europe with area of around 100 thousand hectares. From ISAAA publication, Spain was by far the largest European Union grower with $80 \%$ of the EU total Bt maize crop area (ISAAA, 2013). Smaller amounts of the same crop are produced in Portugal, Slovakia and Czech Republic. Germany and France are the biggest countries in Europe banning genetically modified crop cultivation on its territories. 


\section{A. Andrzejuk}

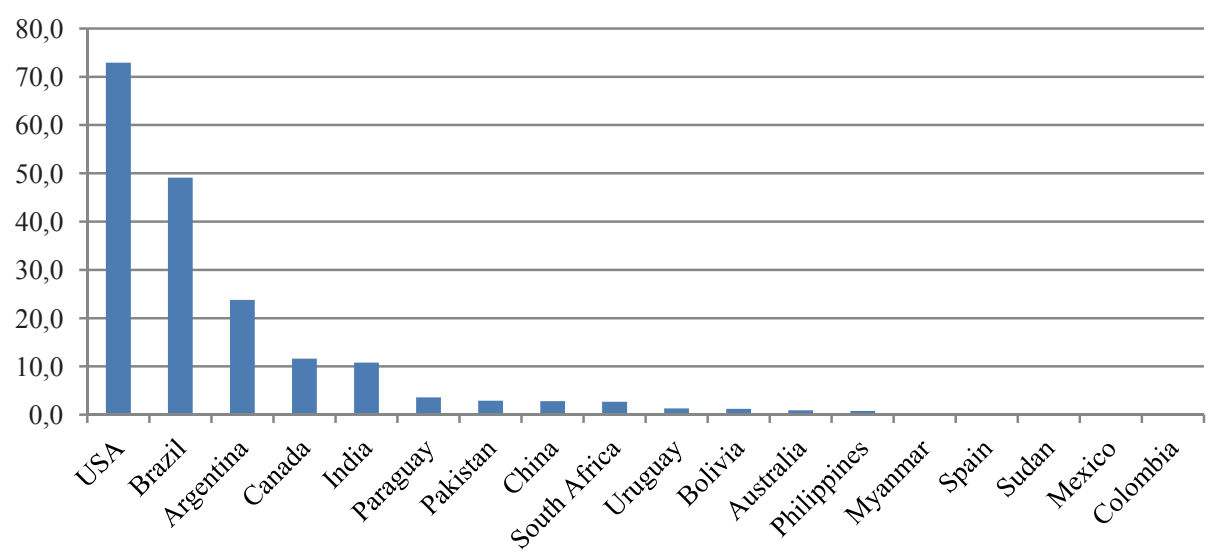

Fig. 2. Global area of biotech crops in 2016 by Country (millions of hectares)

Source: own study based on the data from International Service for the Acquisition of Agri-biotech Applications (ISAAA).

As presented in the table, Soybean, Maize and Cotton account for $95 \%$ of all genetically modified crops cultivated around the world. Out of those three, Soybean represents $50 \%$ of all crops, Maize 33\%, Cotton 12\% and Canola 5\%. Other important GMO's include Escherichia coli K 12 used in cheese-making and carnations used for production of different varieties of flowers. Almost all biotech crops grown commercially worldwide are genetically modified for one or both of two main traits: herbicide tolerance (an estimated 59\% of biotech crops planted in 2011) or insect resistance, i.e. Bt crops, $(15 \%)$ while $26 \%$ have both traits. Commercial release of GM forest trees has been reported in one country, China, and trials with GM trees are taking place in the US. No GM livestock have been commercially released for agricultural purposes (FAO, 2012). However in 2015, fast growing, genetically engineered AquAdvantage Salmon had been approved by Food and Drugs Administration (FDA, 2017). According to FAO, current GM traits such as herbicide tolerance and insect resistance are planned to be extended to other varieties, notably sugar beet, rice, potatoes and wheat, while new releases of virus resistant varieties are expected for fruit, vegetables and wheat. Fungus-resistant crops are also in the pipeline for fruit, vegetables, potatoes and wheat. In addition, efforts are being made to create new traits with greater tolerance to drought, moisture, soil acidity or extreme temperatures (FAO, 2012). There is a lot of noise and suspicion in official publications as to whether or not GM crops increase yields and reduce pesticide usage. However, the documented studies of GM crops according to meta-analysis that aggregates and examines the results of 147 existing research studies looking at GM from Wilhelm Klümper, Matin Qaim, two agricultural economists at Germany's University of Göttingen, found that on average, GM technology adoption has reduced chemical pesticide use by $37 \%$, increased crop yields by $22 \%$, and increased farmer profits by $68 \%$. Yield gains and pesticide reductions are larger for insect-resistant crops than for herbicide-tolerant crops. Yield and profit gains are higher in developing countries than in developed countries (Klümper et. Al, 2014). Other authors also report biomass yield improvement (Rojas, 2010). On the other hand, a study conducted in the United States by Xu, Hennessy, Sardana and Moschini, state that for maize it was 
found that biotech varieties have increased realized yields, with a stronger gain in the Central Corn Belt. For soybeans, biotech crops appear to have slightly reduced yields. However, the combined effects of yield trend and biotech crops adoption are predicted to fall short of the growth rate envisioned by industry projections (Xu et. Al, 2013).

\begin{tabular}{|c|c|c|c|}
\hline Rank & Crops & 2016 & $\%$ \\
\hline 1 & Soybean & 91,4 & 50 \\
\hline 2 & Maize & 60,6 & 33 \\
\hline 3 & Cotton & 22,3 & 12 \\
\hline 4 & Canola & 8,6 & 5 \\
\hline 5 & Alfalfa & 1,2 & $<1$ \\
\hline 6 & Sugar beet & 0,5 & $<1$ \\
\hline 7 & Papaya & $<1$ & $<1$ \\
\hline \multirow[t]{2}{*}{8} & Others & $<1$ & $<1$ \\
\hline & Total & 185,1 & 100 \\
\hline
\end{tabular}

As published by the ISAAA report, economic benefits of planting biotech crops were 15.4 billion USD of which 7.5 billion USD was for developing and 7.9 billion USD for industrial countries. The six countries that economically gained the most from biotech crops in 2015 were: the USA (6.9 billion USD), India (1.3 billion USD), China (1 billion USD), Argentina ( 1.5 billion USD), Brazil (2.5 billion USD), and Canada ( 0.9 billion USD) (ISAAA, 2016).

\section{Biotechnology companies}

Having analyzed the major biotech crops producing countries, as well as, the area of crops around the world, a question has to be stated what entities are involved in research and development of those crops, and which countries have the biggest potential to introduce new biotechnologies to agriculture. To approach the problem, a comparison of the number of biotech companies around the world was conducted including a list of dedicated biotech companies. Biotechnology firms use biotechnology to produce goods or services and/or to perform biotechnology R\&D. Dedicated biotechnology firms devote at least $75 \%$ of their production of goods and services, or R\&D, to biotechnology. From a survey compiled by OECD Health, it's already visible that the country with the highest number of biotechnology companies is the United States with 11554 biotech companies including 934 dedicated. On the second position comes Spain with 2742 biotech companies including 628 dedicated. And in the third place comes France with 1950 biotech companies including 1284 dedicated. In nominal terms, France has the highest number of dedicated biotech firms. All the other 26 countries from the OECD survey have less than 1000 biotech firms. It's also worth mentioning, that the first three leading countries possess $221 \%$ more biotech firm than the rest 26 countries, mostly due to the high concentration of such companies in the United States. Advanced technology clusters, ease of funding and further financing, 


\section{A. Andrzejuk}

strong intellectual property laws, social acceptance for failure and creative environment in academic circles are among myriad of factors influencing development of the biotech industry in the United States.

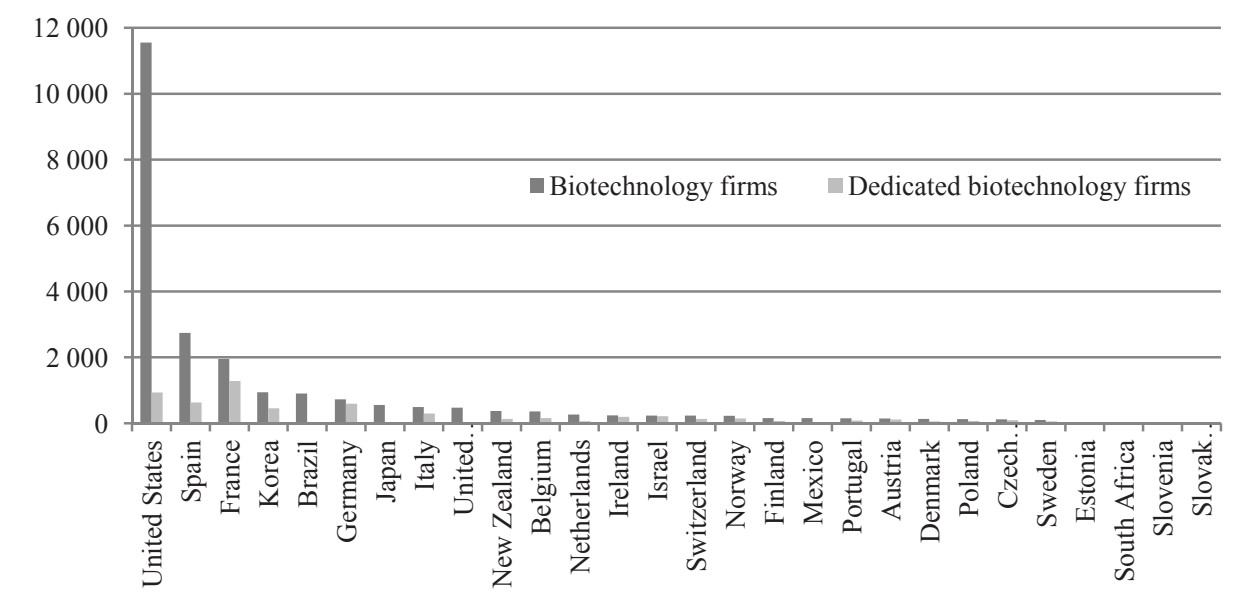

Fig. 3. Number of biotechnology firms and dedicated biotechnology firms in 2014

Source: own study based on data from OECD Health.

Looking more closely at the data, it can be noticed that some countries possess greater potential in biotechnologies by having companies strictly dedicated to biotech research and development.

Table 2. Percentage of dedicated biotechnology firms for specific countries

\begin{tabular}{|c|c|c|c|c|c|}
\hline Rank & Country & $\%$ dedicated & Rank & Country & $\%$ dedicated \\
\hline 1 & Israel & 92,7 & 13 & Poland & 54,8 \\
\hline 2 & Slovak Republic & 86,7 & 14 & Slovenia & 54,2 \\
\hline 3 & Germany & 81,7 & 15 & Sweden & 52,9 \\
\hline 4 & Ireland & 81,4 & 16 & Korea & 48,5 \\
\hline 5 & Austria & 81,1 & 17 & Finland & 44,6 \\
\hline 6 & Estonia & 80,6 & 18 & Belgium & 43,4 \\
\hline 7 & Czech Republic & 79,7 & 19 & Denmark & 43,3 \\
\hline 8 & France & 65,8 & 20 & New Zealand & 36,6 \\
\hline 9 & Norway & 63,1 & 21 & South Africa & 33,3 \\
\hline 10 & Italy & 61,1 & 22 & Netherlands & 24,8 \\
\hline 11 & Switzerland & 57,5 & 23 & Spain & 22,9 \\
\hline \multirow[t]{3}{*}{12} & Portugal & 55,0 & 24 & United States & 8,1 \\
\hline & Average & & & & 56,4 \\
\hline & Median & & & & 54,9 \\
\hline
\end{tabular}

Source: own study based on the data from OECD Health. 
The highest ranks Israel, which despite having in total 233 biotech companies 92,7\% are dedicated to research and development. Second comes the Slovak Republic which has the lowest number of biotech companies among the countries included in the survey, however $86,7 \%$ are dedicated to R\&D in biotech. Third is Germany with $81,7 \%$ of dedicated companies out of 726 in total. Surprisingly, the lowest number of dedicated biotech companies in percentage terms comes from the United States with 8,1\%. However, in nominal terms it still constitutes a substantial number of 934 companies.

The number of entities involved in genetic engineering does not tell the whole story as to how the sector compares is in each country. One must still look at the expenditures devoted to biotech research and development. The table is showing the total biotechnology R\&D expenditures in millions of USD PPP per country, as well as, biotechnology R\&D expenditures as a percentage of Business Expenditures on R\&D (BERD). It can easily be seen that the lion's share of total biotechnology R\&D expenditures are carried out by the firms in the United States which amounts to 38,5 billion USD. France with its second position on the list spends only 3,2 billion USD, and Switzerland being on the third position spends 2,5 billion USD. Interesting insight is presented from the data on biotech R\&D expenditures as a percentage of Business Expenditures on R\&D which can serve as a proxy measure for how much resource is devoted by a country to research on biotechnologies as compared to other technologies. The data shows that the country with the highest percentage of biotech R\&D spending as a percentage to BERD is Switzerland. Other countries with high percentage of biotech R\&D expenditures as a percentage to BERD include Denmark (22\%), Ireland $(17,2 \%)$, Estonia $(13,2 \%)$ and The United States $(12 \%)$.

Table 3. Biotechnology R\&D expenditures in the business sector in 2014

\begin{tabular}{|c|c|c|c|c|c|c|c|}
\hline Rank & Country & $\begin{array}{c}\text { Total } \\
\text { biotechnology } \\
\text { R\&D } \\
\text { expenditures, } \\
\text { MM USD PPP }\end{array}$ & $\begin{array}{c}\text { Biotech R\&D } \\
\text { as a percentage } \\
\text { of BERD }\end{array}$ & Rank & Country & $\begin{array}{c}\text { Total } \\
\text { biotechnology } \\
\text { R\&D } \\
\text { expenditures, } \\
\text { MM USD PPP }\end{array}$ & $\begin{array}{l}\text { Biotech R\&D } \\
\text { as a percentage } \\
\text { of BERD }\end{array}$ \\
\hline 1 & US & 38565,3 & 12,0 & 15 & Canada & 308,4 & 2,5 \\
\hline 2 & France & 3267,9 & 9,1 & 16 & Russia & 223,0 & 0,9 \\
\hline 3 & Switzerland & 2560,0 & 27,8 & 17 & Poland & 189,1 & 4,5 \\
\hline 4 & Korea & 1414,4 & 2,5 & 18 & Czech Rp. & 183,4 & 5,0 \\
\hline 5 & Germany & 1344,0 & 1,8 & 19 & Austria & 177,7 & 2,0 \\
\hline 6 & Japan & 1230,1 & 1,2 & 20 & Norway & 152,2 & 4,9 \\
\hline 7 & Denmark & 1082,2 & 22,0 & 21 & Australia & 120,5 & 1,0 \\
\hline 8 & Spain & 801,4 & 7,9 & 22 & Finland & 111,3 & 2,1 \\
\hline 9 & Belgium & 660,8 & 11,3 & 23 & Portugal & 88,5 & 5,0 \\
\hline 10 & Italy & 603,8 & 3,9 & 24 & SA & 69,6 & 3,0 \\
\hline 11 & Netherlands & 420,2 & 6,9 & 25 & Slovenia & 69,2 & 6,0 \\
\hline 12 & Sweden & 411,7 & 4,2 & 26 & Mexico & 35,4 & 1,1 \\
\hline 13 & Israel & 400,5 & 5,7 & 27 & Estonia & 30,6 & 13,2 \\
\hline 14 & Ireland & 380,9 & 17,2 & 28 & Slovakia & 10,5 & 3,2 \\
\hline \multicolumn{6}{|c|}{ Median } & 344,6 & \\
\hline
\end{tabular}

Source: own study based on the data from OECD Health. 
The research into the role of biotechnology in agriculture around the world wouldn't be complete without knowing how much of the biotechnology R\&D spending goes to various biotech applications. A comparable data collected by OECD Health on this issue is limited to only a few countries. Nevertheless, from the following table it's easily observable that most expenditure on biotechnology is allocated for the healthcare applications with the average of $64,2 \%$ and median of $73,9 \%$. The second highest allocation goes to Industrial processing with the average of $14,6 \%$ and median of $6,6 \%$. The third application goes to food and beverages with the average of 5,7\% and a median of 3,9. Biotechnology R\&D expenditures for agricultural application come only on the fourth place with average rate of expenditures $5,6 \%$ and a median of $3,2 \%$. Despite limited comparable data, an overall picture shows that R\&D expenditures for health applications are much higher on the list of priorities in all surveyed countries than agricultural applications. Therefore most R\&D resource will go to pharmaceutical applications rather than crops. To make a comparison as to the relative size of the crops market vs pharmaceutical market, according to IMS Health, global pharmaceutical production market was valued at 1 trillion USD in 2014. According to FAOSTAT, global agricultural crops market was valued at 2,5 trillion USD in 2016. Despite a much larger size of the crops market over the pharmaceutical market, companies prefer to pour resources into health related biotechnology research and development rather than food related, avoiding public outcry and suspicion in many developed countries.

Table 4. Percentage of biotechnology R\&D by application in 2014

\begin{tabular}{|c|c|c|c|c|c|c|c|c|}
\hline $\begin{array}{l}\text { 咅 } \\
\text { 己 }\end{array}$ & 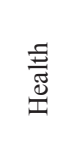 & 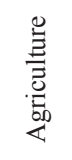 & 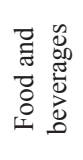 & 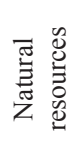 & 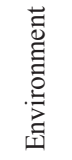 & 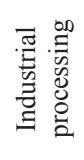 & 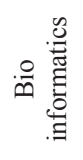 & $\begin{array}{l}\ddot{\bar{g}} \\
\text { D̃ }\end{array}$ \\
\hline Poland & 54,6 & 15,5 & NA & 0,0 & 24,3 & 3,0 & 0,9 & 1,7 \\
\hline Portugal & 25,2 & 12,9 & 18,1 & 2,6 & 7,1 & 18,1 & 5,2 & 11,0 \\
\hline Australia & 72,2 & 11,9 & NA & NA & 9,3 & 6,6 & NA & NA \\
\hline Canada & 76,4 & 9,4 & NA & NA & 4,3 & 9,9 & NA & NA \\
\hline Belgium & 91,4 & 6,8 & 0,4 & NA & 0,3 & 1,1 & NA & 0,0 \\
\hline France & 68,1 & 3,9 & 3,9 & 0,2 & 0,4 & 10,2 & 0,2 & 13,1 \\
\hline Slovenia & 5,4 & 2,5 & NA & NA & 3,6 & 88,5 & NA & NA \\
\hline Italy & 89,6 & 1,7 & 0,6 & 0,0 & 0,1 & 6,7 & 0,3 & 0,9 \\
\hline Korea & 75,5 & 1,6 & 7,7 & 0 & 0,9 & 1,8 & 2,9 & 10,0 \\
\hline Germany & 82,3 & 1,4 & NA & 0,4 & 1,1 & 3,2 & 1,2 & 10,4 \\
\hline Estonia & 37,0 & 0,0 & 9,0 & 19,0 & 0,0 & 23,0 & 8,0 & 4,0 \\
\hline Austria & 92,5 & 0,0 & 0,0 & 0,0 & 0,0 & 2,9 & 0,0 & 4,6 \\
\hline Average & 64,2 & 5,6 & 5,7 & 2,8 & 4,3 & 14,6 & 2,3 & 6,2 \\
\hline Median & 73,9 & 3,2 & 3,9 & 0,1 & 1,0 & 6,6 & 1,1 & 4,6 \\
\hline
\end{tabular}

Source: own study based on the data from OECD Health 


\section{Conclusion}

Despite the perception about ubiquity of genetically modified crops around the world, it was found that biotech crops in agriculture constitute only a small percentage of global crop area, albeit fast growing. It was also found that the benefits of biotechnology are currently reaped by the developed industrial countries as opposed to the developing countries which are mostly in need of productivity increase in agriculture. In 2016 most area of biotech crops was shared among three countries: United States, Brazil and Argentina. Major crops include Soybeans, Maize and Cotton. The highest number of biotech companies can be found in the United States, in 2014 it was 11 554. In Europe in the same year the highest number of biotech firms can be found in Spain (2742), France (1950) and Germany (726), however not all companies calling themselves "biotech" are actually dedicated to biotechnology research and development. The highest percentage of such can be found in Israel, Slovakia, Germany, Ireland, Austria and Estonia. In terms of expenditures on research and development, the United States is the global leader with more than 38 billion USD in 2014, the second largest country in terms of biotech expenditure was France with the amount of around 3,2 billion USD. There is no comparable data on China from OECD. Failure is a common characteristics of the biotech industry. It's worth noting that, due to the favorable climate for start-up companies, advanced technology clusters, ease of funding, and social acceptance for failure among others, the highest number of biotech companies and the highest spending is concentrated in the US. At the same time it was found that Switzerland and Denmark spend the highest proportion of $R \& D$ funds on biotechnology as compared to $R \& D$ in other areas. It's important to notice that agricultural biotechnology constitute only a small percentage of all biotechnology R\&D expenditures. In 2014 most of the biotech R\&D funding went to pharmaceutical applications with the median of $73,9 \%$ and industrial processing $6,6 \%$. The median for agricultural biotechnology was $3,2 \%$. Almost all biotech crops grown commercially worldwide are genetically modified for one or both of two main traits: herbicide tolerance or insect resistance. Efforts are being made to create new traits with greater tolerance to drought, moisture, soil acidity or extreme temperatures. In 2015, a fast growing, genetically engineered AquAdvantage Salmon had been approved by Food and Drugs Administration.

\section{References}

FAOSTAT (2017). Land use. Accessed 23 October 2017 from: http://www.fao.org/faostat/en/\#data/RL.

FAO, Earthscan (2003). World agriculture: towards 2015/2030. Accessed 23 October 2017 from: http://www.fao.org/3/a-y4252e.pdf.

FAO, GMOs in the pipeline: Looking to the next five years in the crop, forestry, livestock, aquaculture and agroindustry sectors in developing countries, (2012). World agriculture: towards 2015/2030. Accessed 23 October 2017 from: http://www.fao.org/docrep/016/ap109e/ap109e00.pdf.

FAO (2014). Low Levels of Genetically Modified Crops in International Food and Feed Trade: FAO International Survey and Economic Analysis. Accessed 23 October 2017 from: http://www.fao.org/docrep/019/i3734e/ i3734e.pdf.

FDA (2017). AquAdvantage Salmon Fact Sheet. Accessed 23 October 2017 from: https://www.fda.gov/AnimalVet erinary/DevelopmentApprovalProcess/GeneticEngineering/GeneticallyEngineeredAnimals/ucm473238.htm.

ISAAA (2017). International Service for the Acquisition of Agri-biotech Applications, Biotech Crop Highlights in 2016. Accessed 23 October 2017 from: http://www.isaaa.org/resources/publications/pocketk/16/. 


\section{A. Andrzejuk}

ISAAA (2016). International Service for the Acquisition of Agri-biotech Applications, Global Status of Commercialized Biotech/GM Crops: 2016. Accessed 23 October 2017 from: https://www.isaaa.org/resources/publications/briefs/52/download/isaaa-brief-52-2016.pdf.

Klümper, W., Qaim, M. (2014). A Meta-Analysis of the Impacts of Genetically Modified Crops. PLoS ONE, 9(11): e111629. doi:10.1371/journal.pone.0111629.

OECD (2009). The bioeconomy is key to tackling many future global challenges, says OECD. Accessed 23 October $2017 \quad$ from: http://www.oecd.org/science/thebioeconomyiskeytotacklingmanyfutureglobalchallengessays oecd.htm.

PBS \& ABSPII (2004). Agricultural Biotechnology Support Project. Accessed 23 October 2017 from: http://absp2.cornell.edu/resources/briefs/documents/warp_briefs_eng_scr.pdf.

Rojas, C.A., Hemerly, A.S., Gomes Ferreira, P.C. (2010). Genetically modified crops for biomass increase. Genes and strategies. GM Crops, 1(3), 137-142.

UN - United Nations, DESA - Population Division (2017). World Population Prospects 2017. Accessed 23 October 2017 from: https://esa.un.org/unpd/wpp/DataQuery/.

UNICEF (2017). Monitoring the situation of Children and Women. Accessed 23 October 2017 from: https://data.unicef.org/topic/nutrition/malnutrition/.

Xu, Z., Hennessy, D., A., Sardana, K., Moschini, G. (2013). The Realized Yield Effect of Genetically Engineered Crops: U.S. Maize and Soybean. Crop Science, 53, 735-745. 